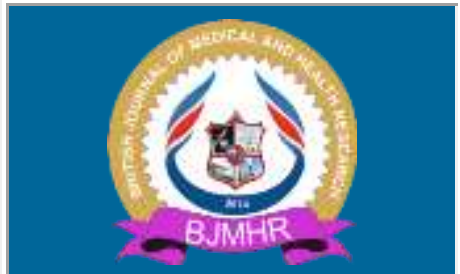

\title{
BJMHR
}

British Journal of Medical and Health Research Journal home page: www.bjmhr.com

\section{Phytochemical Investigation and in vitro Bioactivity Analysis of Lindenbergia Indica}

\section{Farina Aziz ${ }^{1 *}$, Muhammad Abdullah Al-Mansur ${ }^{2}$, Choudhury Mahmood Hasan', Monira Ahsan ${ }^{1}$ \\ 1.Department of Pharmaceutical Chemistry, Faculty of Pharmacy, University of Dhaka, Dhaka-1000, Bangladesh. \\ 2.Institute of National Analytical Research and Service (INARS), BCSIR Laboratories, Dr. Quadrat-I-Khuda Road, Dhanmondi, Dhaka-1205, Bangladesh.}

\section{ABSTRACT}

Lidenbergia indica Vatke or wall lindenbergia belongs to the family Scrophulariaceae which includes a number of ethnopharmacologically important Himalayan medicinal plants. The juice of the plant is used in chronic bronchitis and skin eruptions. The crude ethyl acetate extract of the whole plants of Lidenbergia indica led to the isolation of two flavonoids, luteolin and apigenin, methyl-4-methoxy cinnamate and $\beta$-sitosterol by different chromatographic techniques. The petroleum ether, chloroform, ethyl acetate and aqueous fractions were evaluated for biological properties using established methods. In vitro antioxidant activity was studied with DPPH radical scavenging method using butylated hydroxyl anisole as standard. The ethyl acetate fraction of the plant showed prominent free radical scavenging activity. The petroleum ether soluble fraction of Lindenbergia indica demonstrated highest thrombolytic activity. However, the other partitionates i.e. chloroform, ethyl acetate and aqueous extract showed minimum thrombolytic activity compared to the standard streptokinase. In the cytotoxic activity assay using brine shrimp, the petroleum ether, chloroform and ethyl acetate fraction showed significant lethality whereas aqueous fraction showed negligible lethal activity as compared to standard vincristine sulphate. No antimicrobial activity was observed for the petroleum ether, chloroform, ethyl acetate and aqueous fractions against all the microorganisms tested using tetracycline, levofloxacin, azithromycin and ciprofloxacin as standard.

Keywords: Lidenbergia indica, Scrophulariaceae, Luteolin, Apigenin, Methyl-4-methoxy cinnamate, Antioxidant.

*Corresponding Author Email: azizfarinadu@ gmail.com

Received 10 July 2019, Accepted 22 July 2019

Please cite this article as: Aziz F et al., Phytochemical Investigation and in vitro Bioactivity Analysis of Lindenbergia Indica. British Journal of Medical and Health Research 2019. 


\section{INTRODUCTION}

Lidenbergia indica Vatke also known as haldi basanti (Bengali) or wall lindenbergia (English), is an annual herb belonging to the family Scrophulariaceae. The plant grows as a common weed bearing yellow axillary flowers, particularly on old walls in different Asian countries including Bangladesh, India, Malaysia, China and tropical Africa $(1,2)$. The family Scrophulariaceae is well known for producing a number of economically important and medicinal plants. It is a rich source of traditional medicines, and the Ayurvedic, Unani, Siddha, Tibetan and other nonformal traditional systems of medicine have been using these plant species from time immemorial (3). The family produces secondary metabolites of diverse chemical nature, such as alkaloids, diterpenes, triterpenes, flavonoids, iridoid glycosides, saponins (4-9) etc.

The juice of the plant is usually given in chronic bronchitis, sore throat, toothache and skin eruptions. Different parts of the plant contain a large number of long chain hydrocarbons, $\beta$ sitosterol, $\beta$-sitosterol palmitate, $\beta$-sitosterol- $\beta$-D-glucoside, mannitol and apigenin $(1,2)$. We, herein, report the isolation of two flavonoids, luteolin and apigenin, a cinnamic acid derivative, methyl-4-methoxy cinnamate and $\beta$-sitosterol from this plant and the evaluation of antioxidant, thrombolytic, cytotoxic and antimicrobial activities of different fractions of the extracts collected from the plant.

\section{MATERIALS AND METHOD}

\section{General experimental procedures}

Silica gel 60 PF254 (0.5 mm thickness, Merck) coated glass plates were used to conduct preparative TLC and vanillin $\mathrm{H}_{2} \mathrm{SO}_{4}$ spray reagent were used to detect compounds. Sephadex LH-20 was used to perform gel permeation chromatography. NMR spectra were measured at $400 \mathrm{MHz}$ for $1 \mathrm{H}$ NMR spectra and $100 \mathrm{MHz}$ for 13C NMR on a Bruker $400 \mathrm{MHz}$ NMR spectrometer. The whole plant of Lindenbergia indica was collected in the month of January, 2018 from Barisal district, Bangladesh. A voucher specimen had been maintained in the National herbarium of Bangladesh under the accession number 46559 for future reference.

\section{Extraction and isolation}

The air-dried powdered plant material (whole plant) $2.5 \mathrm{Kg}$ was soaked in distilled methanol (5 L) for 2 weeks and filtered through a cotton plug. The extract was then concentrated under reduced pressure using a Buchii rotary evaporator. From the crude extract, an aliquot of the ethyl acetate soluble fraction $(38.5 \mathrm{~g})$ was separated. This was further subjected to fractionation to obtain 33 fractions by vacuum liquid chromatography (VLC) using silica gel $60 \mathrm{H}$ and hexane, ethyl acetate and methanol in increasing order of polarity.

\section{Compound 1:}


Compound 1 was collected as orange crystals from VLC fraction 27(2\% methanol in ethyl acetate). It was purified by gel permeation chromatography using Sephadex LH-20 followed by PTLC using toluene and ethyl acetate in the ratio of 40:60 as the solvent system. It also showed quenching spot under UV light $(254 \mathrm{~nm})$ on TLC plate and produced a yellowish spot after spraying with vanillin-sulfuric acid reagent followed by heating at $110{ }^{\circ} \mathrm{C}$ for $2 \mathrm{~min}$. The ${ }^{1} \mathrm{H}$ NMR (400 MHz, CD $\left.3 \mathrm{OD}\right): \delta 6.44(1 \mathrm{H}, \mathrm{s}, \mathrm{H}-3), \delta 6.11$ (1H, d, J=2.14 Hz, H-6), $\delta 6.34(1 \mathrm{H}$, d, $J=2.14 \mathrm{~Hz}, \mathrm{H}-8), \delta 7.27$ (1H, d, $\left.J=1.9 \mathrm{~Hz}, \mathrm{H}-2^{\prime}\right), \delta 6.81\left(1 \mathrm{H}, \mathrm{d}, J=8.48 \mathrm{~Hz}, \mathrm{H}-5^{\prime}\right), \delta 7.28(1 \mathrm{H}$, dd, $\left.J=8.48,1.9 \mathrm{~Hz}, \mathrm{H}-6^{\prime}\right)$.

\section{Compound 2:}

Compound 2 was collected as yellow crystals from VLC fraction 26 (100\% ethyl acetate). It was purified by gel permeation chromatography using Sephadex LH-20 followed by repeated crystallization of the concentrated sephadex fraction. It showed quenching under UV light $(254 \mathrm{~nm})$ on TLC plate and showed a lemonish yellow spot after spraying with vanillin-sulfuric acid reagent followed by heating at $110{ }^{\circ} \mathrm{C}$ for 2 minutes. The ${ }^{1} \mathrm{H}$ NMR (400 MHz, CD $\left.3 \mathrm{OD}\right)$ : $\delta 6.62(1 \mathrm{H}, \mathrm{s}, \mathrm{H}-3), \delta 6.23(1 \mathrm{H}, \mathrm{br} \mathrm{s}, \mathrm{H}-6), \delta 6.48(1 \mathrm{H}, \mathrm{br} \mathrm{s}, \mathrm{H}-8), \delta 7.88(2 \mathrm{H}, \mathrm{d}, J=8.6 \mathrm{~Hz}, \mathrm{H}-$ $\left.2^{\prime}, 6^{\prime}\right), \delta 6.95\left(2 \mathrm{H}, \mathrm{d}, J=8.6 \mathrm{~Hz}, \mathrm{H}-3^{\prime}, 5^{\prime}\right)$

\section{Compound 3:}

Compound 3 was isolated from VLC fraction 12 (20\% ethyl acetate in hexane) as white crystalline mass. It was purified by gel permeation chromatography using Sephadex LH-20 followed by PTLC using toluene and ethyl acetate in the ratio of 80:20 as the solvent system. It showed quenching spot under UV light ( $254 \mathrm{~nm}$ ) on TLC plate and produced no color after spraying with vanillin-sulfuric acid reagent followed by heating at $110{ }^{\circ} \mathrm{C}$ for $2 \mathrm{~min}$. The $1 \mathrm{H}$ NMR (400 MHz, $\left.\mathrm{CD}_{3} \mathrm{Cl}_{3}\right): \delta 7.48(2 \mathrm{H}, \mathrm{d}, J=8.2 \mathrm{~Hz}, \mathrm{H}-2,6), \delta 6.92(2 \mathrm{H}, \mathrm{d}, J=8.2 \mathrm{~Hz}, \mathrm{H}-3,5)$, $\delta 7.65(1 \mathrm{H}, \mathrm{d}, J=15.8 \mathrm{~Hz}, \mathrm{H}-7), \delta 6.31(1 \mathrm{H}, \mathrm{d}, J=15.8 \mathrm{~Hz}, \mathrm{H}-8), \delta 3.85\left(3 \mathrm{H}, \mathrm{s}, \mathrm{OCH}_{3}-4\right), \delta 3.80$ $\left(3 \mathrm{H}, \mathrm{s},, \mathrm{OCH}_{3}-9\right)$.

\section{Compound 4:}

Compound 4 was isolated as needle-shaped crystals from VLC fraction 15 (25\% ethyl acetate in hexane) which produced dark purple color on thin layer chromatography after spraying with vanillin-sulfuric acid reagent followed by heating at $110{ }^{\circ} \mathrm{C}$ for $2 \mathrm{~min}$. The $1 \mathrm{H}$ NMR (400 $\left.\mathrm{MHz}, \mathrm{CD}_{3} \mathrm{Cl}_{3}\right): \delta 3.54(1 \mathrm{H}, \mathrm{m}, \mathrm{H}-3), \delta 5.36\left(1 \mathrm{H}\right.$, br s, H-6), $\delta 0.70\left(3 \mathrm{H}, \mathrm{s}, \mathrm{CH}_{3}-18\right), \delta 1.03(3 \mathrm{H}$, s, $\left.\mathrm{CH}_{3}-19\right), \delta 0.93$ (d, J=6.5 Hz, $\left.\mathrm{CH}_{3}-21\right), \delta 0.82$ (d, J=6.5 Hz, $\left.\mathrm{CH}_{3}-26\right), \delta 0.84$ (d, J=6.5 Hz, $\left.\mathrm{CH}_{3}-27\right), \delta 0.87$ (t, J=7.6 Hz, $\mathrm{CH}_{3}-29$ ).

\section{Preparation of sample for biological investigation}

An aliquot $(5 \mathrm{~g})$ of the crude methanolic extract was fractionated by the modified Kupchan partitioning method (10) for biological activity. The crude extract was dissolved in $10 \%$ 
aqueous methanol to make the mother solution which was successively partitioned by petroleum ether, chloroform, ethyl acetate and water in order of increasing polarity by using separating funnel.

\section{Antioxidant activity:}

The antioxidant activity was evaluated following DPPH assay, designed by Brand-Williams et al (11) was selected. The antioxidant potential was assayed from the bleaching of purple colored methanol solution of DPPH radical by the plant extract as compared to that of Butylated Hydroxy Anisole (BHA) by UV spectrophotometer.

\section{Thrombolytic property:}

In vitro clot lysis activity of the plant $L$. indica was carried out according to the method of Prasad et al (12). The thrombolytic property was assessed by standard streptokinase (100 $\mu \mathrm{L})$ as positive control and water as negative control. Whole blood was drawn from healthy human volunteers without a history of oral contraceptives or anticoagulant therapy.

\section{Brine shrimp lethality bioassay:}

To investigate potential cytotoxic effect, the method designed by Meyer et al (13) was chosen. Vincristine sulphate was used as positive control.

\section{Antimicrobial activity assay:}

The method described by Bauer et al. (14) was selected for the current study for screening antimicrobial activity against two Gram-positive bacteria (Staphylococcus aureus, Bacillus subtilis) and five Gram-negative bacteria (Shigella flexneri, Salmonella typhi, Escherichia coli, Pseudomonas aeruginosa, Vibrio cholerae). Sterile blank discs and standard antibiotic discs (ciprofloxacin $5 \mu \mathrm{g} /$ disc, levofloxacin $5 \mu \mathrm{g} /$ disc, azithromycin $15 \mu \mathrm{g} / \mathrm{disc}$, tetracycline 30 $\mu \mathrm{g} /$ disc) were used as negative and positive controls respectively. The test samples were loaded on the discs at a concentration of $400 \mu \mathrm{g} / \mathrm{disc}$. The antimicrobial activity of the test samples were than evaluated by measuring the zone of inhibition.

\section{RESULTS AND DISCUSSION}

\section{Chemical investigation of Lindenbergia indica}

The ethyl acetate soluble fraction of the plant L. indica (Family: Scrophulariaceae) was investigated for isolation of the potent secondary metabolites from this plant. Successive chromatographic separation and purification yielded four compounds and the structures were solved as luteolin, apigenin, methyl-4-methoxy cinnamate and $\beta$-sitosterol. 
<smiles>O=c1cc(-c2ccc(O)c(O)c2)oc2cc(O)cc(O)c12</smiles>

Luteolin<smiles>COC(=O)/C=C/c1ccc(OC)cc1</smiles>

Methyl-4-methoxy cinnamate

\section{Luteon..}<smiles>O=c1cc(-c2ccc(O)cc2)oc2cc(O)cc(O)c12</smiles>

Apigenin

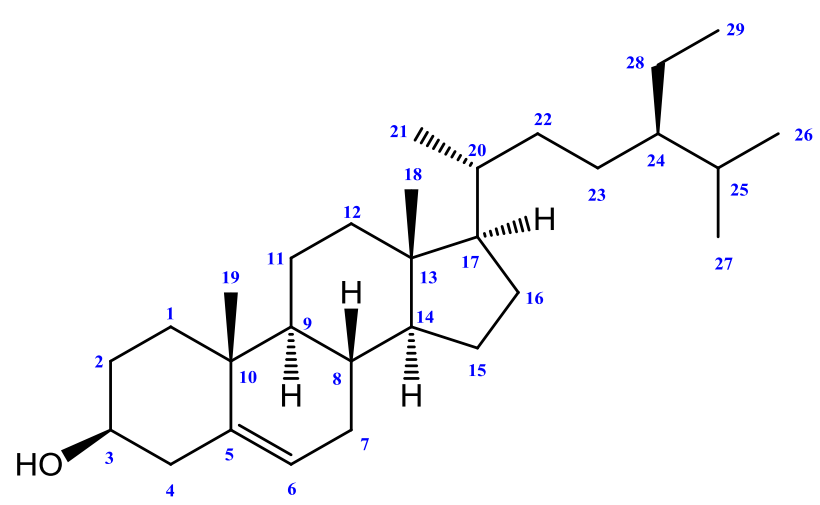

The ${ }^{1} \mathrm{H}$ NMR spectrum of compound $\mathbf{1}$ showed a pair of meta coupled protons at $\delta 6.11,6.34$ and 7.27. The spectra also revealed the presence of one ortho coupled aromatic doublet at 6.81 , one doublet of doublets at 7.28 corresponding to an ortho and meta coupled aromatic proton, and a singlet at 6.44 which is characteristic for a $5,7,3^{\prime}, 4^{\prime}$ - tetra substituted flavone. The identity of compound 1 was confirmed as luteolin $\left(5,7,3^{\prime}, 4^{\prime}-\right.$ tetrahydroxyflavone) by comparison of its proton NMR data with those reported for the compound (15). The compound has been isolated for the first time from this plant.

\section{Apigenin:}

The ${ }^{1} \mathrm{H}$ NMR spectrum of compound 2 showed the presence of two meta coupled aromatic doublets at $\delta 6.23$ and 6.48 corresponding to H-6 and H-8 protons and two doublet of doublets at $\delta 6.95$ and 7.88 for $\mathrm{H}-3^{\prime} / \mathrm{H}-5^{\prime}$ and $\mathrm{H}-2^{\prime} / \mathrm{H}-6^{\prime}$ protons. The spectra also revealed a singlet at 6.62 corresponding to H-3 proton which is characteristic for a 5,7,4'- trisubstituted flavone. The identity of compound 2 was confirmed as apigenin (5,7,4'-trihydroxyflavone) by comparison of its proton NMR data with those reported for the compound (16).

\section{Methyl-4-methoxy cinnamate:}

The ${ }^{1} \mathrm{HNMR}$ spectrum of compound 3 displayed two doublets at $\delta 6.92(\mathrm{~J}=8.2 \mathrm{~Hz})$ and $\delta 7.48$ $(J=8.2 \mathrm{~Hz})$ that have been attributed to $\mathrm{H}-3 / \mathrm{H}-5$ and $\mathrm{H}-2 / \mathrm{H}-6$ of the coumaryl moiety, respectively. The spectra also revealed the presence of a pair of doubles at $\delta 7.65(\mathrm{~J}=15.8 \mathrm{~Hz})$ 
and $6.31(J=15.8 \mathrm{~Hz})$ suggestive of trans-olefinic protons. The spectrum further showed two singlets at $\delta 3.85(3 \mathrm{H})$ and $3.80(3 \mathrm{H})$ indicating the presence of two $-\mathrm{OCH}_{3}$ groups, the values of which are interchangeable. The respective proton NMR data are closely in agreement with those reported for $p$-methoxy cinnamic acid (17) with an additional $-\mathrm{OCH}_{3}$ group; thus establishing the structure as 4-methoxy cinnamic acid methyl ester. The compound has been isolated for the first time from this plant.

\section{$\beta$-sitosterol:}

Compound 4 was isolated as needle-shaped crystals from VLC fraction 15 which produced dark purple color on thin layer chromatography after spraying with vanillin-sulfuric acid reagent followed by heating at $110^{\circ} \mathrm{C}$ for $2 \mathrm{~min}$. The identity of the compound 4 was confirmed as $\beta$-sitosterol bycomparing the proton NMR data of the compound with those reported earlier for it (18).

\section{Antioxidant activity:}

Different organic fractions of Lindenbergia indica were subjected to evaluation of antioxidant activity by the method suggested by Brand-William et al. The $\mathrm{IC}_{50}$ value of BHA was used as reference which was $6.82 \mu \mathrm{g} / \mathrm{mL}$. In this investigation, the ethyl acetate fraction of the plant showed significant free radical scavenging activity with $\mathrm{IC}_{50}$ value $11.49 \mu \mathrm{g} / \mathrm{ml}$ whereas the aqueous fraction exhibited moderate activity with $\mathrm{IC}_{50}$ value $32.09 \mu \mathrm{g} / \mathrm{ml}$ (Table-1).

Table 1: Antioxidant activity of different fractions of $L$. indica:

\begin{tabular}{ll}
\hline Sample & $\begin{array}{l}\text { Free radical scavenging } \\
\text { activity }(\mathbf{I C} \mathbf{5 0}, \boldsymbol{\mu g} / \mathbf{m L})\end{array}$ \\
\hline BHA & $6.82 \pm 0.03$ \\
Petroleum ether fraction & $110.95 \pm 0.16$ \\
Chloroform fraction & $135 \pm 0.07$ \\
Ethyl acetate fraction & $11.49 \pm 0.13$ \\
Aqueous fraction & $32.09 \pm 0.23$ \\
\hline
\end{tabular}

The data are displayed with mean \pm standard deviation of triplicate studies.

Mean values followed by different superscript in a column are significantly different $(\mathrm{p}<0.05)$.

Thrombolytic property:

The extractives of the plant $L$. indica showed moderate thrombolytic activity. In this study, the petroleum ether soluble fraction of Lindenbergia indica demonstrated highest thrombolytic activity (68.85\%). However, the other partitionates i.e. chloroform, ethyl acetate and aqueous extract showed minimum thrombolytic activity compared to the standard streptokinase (70.52\%) (Table 2). 
Table 2: Thrombolytic activity (in terms of \% of clot lysis) of different fractions of $L$. Indica:

\begin{tabular}{ll}
\hline Sample & Clot lysis (\%) \\
\hline Negative control (water) & $5.52 \pm 0.37$ \\
Petroleum ether fraction & $68.85 \pm 1.75$ \\
Chloroform fraction & $33.42 \pm 2.05$ \\
Ethyl acetate fraction & $30.07 \pm 2.02$ \\
Aqueous fraction & $25.12 \pm 1.62$ \\
Positive control (Streptokinase) & $70.52 \pm 0.99$ \\
\hline
\end{tabular}

The data are displayed with mean \pm standard deviation of triplicate studies.

Mean values followed by different superscript in a column are significantly different $(\mathrm{p}<0.05)$.

\section{Brine shrimp lethality bioassay:}

The $\mathrm{LC}_{50}$ value of vincristine sulphate was used as reference which was found to be 0.37 $\mu \mathrm{g} / \mathrm{mL}$. In this investigation, the petroleum ether (1.081), chloroform (1.538) and ethyl acetate (1.602) fraction showed significant lethality whereas aqueous fraction showed negligible lethal activity (Table 3 ).

\section{Table 3: LC50 values of different fractions of $\boldsymbol{l}$. Indica}

\begin{tabular}{ll}
\hline Sample & $\mathrm{LC}_{50}(\mu \mathrm{g} / \mathrm{mL})$ \\
\hline Positive control (Vincristine sulphate) & $0.37 \pm 0.20$ \\
Petroleum ether fraction & $1.081 \pm 0.69$ \\
Chloroform fraction & $1.538 \pm 0.80$ \\
Ethyl acetate fraction & $1.602 \pm 0.65$ \\
Aqueous fraction & $620.01 \pm 0.95$ \\
\hline
\end{tabular}

The data are displayed with mean \pm standard deviation of triplicate studies.

Mean values followed by different superscript in a column are significantly different $(\mathrm{p}<0.05)$.

\section{Antimicrobial activity assay:}

In the microbiological investigation, none of the organic fractions of Lindenbergia indica did not demonstrate any appreciable activity against any species as compared with ciprofloxacin, levofloxacin, tetracycline and azithromycin standards.

\section{CONCLUSION}

Among the four compounds reported, luteolin and methyl-4-methoxy cinnamate are isolated for the first time from the plant Lindenbergia indica. From the results of different biological screening test, it may be concluded that different fraction of the plant Lindenbergia indica have significant antioxidant and cytotoxic properties as well as mild to moderate thrombolytic activity. Therefore, considering the potential bioactivity and scope for further chemical screening, the plant material can further be studied extensively to isolate novel natural compounds and expand the horizon of biological efficacy testing, which may lead to many potentially active drug candidates from this plant. 


\section{REFERENCES}

1. Ghani A. Medicinal Plants of Bangladesh with Chemical Constituents and Uses. $2^{\text {nd }}$ edition, Asiatic Society of Bangladesh; 2003: 280.

2. Singh M, Walia S, Singh AK. Phytochemical characterization and antibacterial activity of Lindenbergia indica Vatke: A common wall flora against some human pathogens in Doon Valley, Uttarakhand. Indian Journal of Natural Product Resources. 2013; 4:138145.

3. Srivastava DK, Saggoo MIS. Few medicinal plants of family Labiatae and Scrophulariaceae in the high altitude cold desert areas of Lahaul-Spiti and its adjoining areas of Himachal Pradesh (India). 'INSIGHT' an International Journal of Science. 2015; $2: 75-81$.

4. Stermitz FR, Belofsky GN, Ng D, Singer MC. Quinolizidine alkaloids obtained by Pedicularis semibarbata (Scrophulariaceae) from Lupinus fulcratus (Leguminosae) fail to influence the specialist herbivore Euphydryas editha (Lepidoptera). Journal of Chemical Ecology. 1989; 15: 2521-2530.

5. Ahsan M, Islam SKN., Gray AI, Stimson WH. Cytotoxic diterpenes from Scoparia dulcis. Journal of Natural Products. 2003; 66: 958-961

6. Chen CM, Chen MT. 6-Methoxybenzoxazolinone and triterpenoids from roots of Scoparia dulcis. Phytochemistry. 1976;15:1997-1999.

7. Mahato SB, Das MC, Sahu NP. Triterpenoids of Scoparia dulcis. Phytochemistry. $1981 ; 20: 171-173$.

8. Pasdaran A, Hamedi A. The genus Scrophularia : a source of iridoids and terpenoids with a diverse biological activity. Pharmaceutical Biology. 2017; 55: 2211-2233.

9. Nikkhah E, Afshar FH, Babaei H, Asgharian P, Delazar A. Phytochemical analysis and in-vitro bioactivity of Scrophularia umbrosa rhizome (Scrophulariaceae). Iranian Journal of Pharmaceutical Research. 2018; 17: 685-694.

10. VanWagenen BC, Larsen R, Cardellina JH, Randazzo D, Lidert ZC, Swithenbank C. Ulosantoin, a potent insecticide from the Sponge Ulosa ruetzleri. Journal of Organic Chemistry. 1993; 58: 335-337.

11. Brand-Williams W, Cuvelier M, Berset C. Use of a free radical method to evaluate antioxidant activity. LWT- Food Science and Technology. 1995; 28: 25-30.

12. Prasad S, Kashyap RS, Deopujari JY, Purohit HJ, Taori GM, Daginawala HF. Development of an in vitro model to study clot lysis activity of thrombolytic drugs. Thrombosis Journal. 2006; 4: 9-12.

13. Meyer BN, Ferrigni NR, Putnam JE, Jacobsen LB, Nichols DE, McLaughlin JL. Brine 
Shrimp: a convenient general bioassay for active plant constituents. Journal of Medicinal Plant Research. 1982; 45:31-34.

14. Bauer AW, Kirby WM, Sherris JC, Turck M. Antibiotic susceptibility testing by a standardized single disk method. American Journal of Clinical Pathology. 1966; 45: 493-496.

15. Wahab A, Tahira, Begum S, Ayub A, Mahmood I, Mahmood T, Ahmad A, Fayyaz N. Luteolin and kaempferol from Cassia alata, antimicrobial and antioxidant activity of its methanolic extracts. FUUAST Journal of Biology. 2014; 4: 1-5.

16. Benayache F, Boureghda A, Ameddah S, Marchioni E, Benayache F, Benayache S. Flavonoids from thymus numidicus poiret. Der Pharmacia Lettre. 2014; 6: 50-54.

17. W Bylka. E- and Z-p-methoxycinnamic acid from Aquilegia vulgaris. Acta poloniae pharmaceutica. 2004; 61: 307-308.

18. Pateh U, Haruna A, Garba M, Iliya I, Sule I, Abubakar M, Ambi A. Isolation of stigmasterol , $\beta$-sitosterol and 2- hydroxyhexadecanoic acid methyl ester from the rhizomes of Stylochiton lancifolius Pyer and Kotchy. Nigerian Journal of Pharmaceutical Sciences. 2009; 8: 19-25.

\section{BJMHR is \\ - Peer reviewed \\ - Monthly \\ - Rapid publication \\ - Submit your next manuscript at editor@bjmhr.com

